\title{
RANCANG BANGUN SISTEM INFORMASI PENDUKUNG KEPUTUSAN PENENTUAN DESA SIAGA DI PUSKESMAS KALIBAGOR KABUPATEN BANYUMAS
}

\author{
Linda Perdanawanti \\ Dosen Program Studi Sistem Informasi, STMIK AMIKOM Purwokerto \\ perdanamine@gmail.com
}

\begin{abstract}
ABSTRAKS
Desa siaga adalah desa yang penduduknya memiliki kesiapan sumber daya dan kemampuan serta kemauan untuk mencegah dan mengatasi masalah-masalah kesehatan, bencana dan kegawatdaruratan kesehatan secara mandiri. Data kriteria penentuan desa siaga yaitu keberadaan dan keaktifan forum desa, keberadaan kader pemberdayaan masyarakat, kemudahan akses masyarakat terhadap pelayanan kesehatan, keberadaan UKBM, tercakupnya pendanaan untuk pengembangan desa, peran serta aktif masyarakat dan organisasi kemasyarakatan, peraturan ditingkat desa yang melandasi dan mengatur tentang pengembangan desa, pembinaan Perilaku Hidup Bersih dan Sehat (PHBS) di desa baik di lingkungan desa maupun masyarakatnya. Pencapaian target desa siaga di setiap desa di Kecamatan Kalibagor memerlukan data. Data-data tersebut didapatkan dari pelayanan kesehatan yang dilakukan di puskesmas setiap bulannya, pemantauan wilayah setempat yang dilakukan di masing-masing desa. Dengan memanfaatkan suatu sistem informasi penunjang keputusan maka akan diperoleh desa siaga di suatu desa di Kecamatan Kalibagor. Sistem informasi penunjang keputusan yang dibuat menggunakan metode Fuzzy AHP. Hasil penelitian ini akan menghasilkan desa siaga yang akan membandingkan setiap kriteria agar tercapai target sesuai dengan indikator desa siaga.
\end{abstract}

Kata Kunci: Sistem Penunjang Keputusan, Kesehatan Ibu dan Anak, Fuzzy AHP PENDAHULUAN

Desa siaga adalah desa yang penduduknya memiliki kesiapan sumber daya dan kemampuan serta kemauan untuk mencegah dan mengatasi masalah-masalah kesehatan, bencana dan kegawatdaruratan kesehatan secara mandiri. Sebuah Desa dikatakan menjadi desa siaga apabila desa tersebut telah memiliki sekurang- 
kurangnya sebuah Pos Kesehatan Desa (Poskesdes) (Depkes, 2007) [1]. Pengembangan desa siaga merupakan upaya memberdayakan masyarakat agar memiliki kesiapan sumber daya dan kemampuan serta kemauan untuk mencegah dan mengatasi masalah-masalah kesehatan, bencana dan kegawat daruratan kesehatan secara mandiri, khususnya di bidang kesehatan ibu dan anak. UKBM (Upaya Kesehatan Bersumber Daya Masyarakat) yang dibentuk di desa dalam rangka upaya mendekatkan pelayanan kesehatan dasar bagi masyarakat desa. Poskesdes dikelola oleh satu orang bidan dan minimal dua orang kader dan merupakan koordinator dari UKBM. Pelayanan kesehatan dasar sesuai dengan kewenangan bidan, bila tidak dapat ditangani dirujuk ke Puskesmas Pembantu atau Puskesmas. (KMK RI No 564 tentang Pedoman Pelaksanaan Pengembangan Desa Siaga) ${ }^{[2]}$. Kriteria penetuan desa siaga adalah sebagai berikut:

Caranya adalah dengan membandingkan secara berpasangan keunggulan tiap-tiap desa pada kriteria berikut ini:

1. Kepedulian pemerintah desa

2. Keberadaan kader pemberdayaan masyarakat

3. Kemudahan akses masyarakat terhadap pelayanan kesehatan dasar

4. Keberadaan UKBM (Upaya Kesehatan Bersumber Daya Masyarakat)

5. Tercakupnya pendanaan untuk pengembangan desa

6. Peran serta aktif masyarakat dan ormas dalam kegiatan kesehatan

7. Peraturan ditingkat desa yang mengatur tentang pengembangan desa

8. Pembinaan Perilaku Hidup Bersih dan Sehat (PHBS) di desa

Puskesmas Kalibagor adalah salah satu unit pelayanan kesehatan masyarakat yang mencakup 12 desa di Kecamatan Kalibagor sudah selayaknya memberikan pelayanan ke semua desa tersebut. Pencapaian target di setiap desa di Kecamatan Kalibagor memerlukan data. Data-data tersebut didapatkan dari pelayanan kesehatan yang dilakukan di puskesmas setiap bulannya. Data kemudian diolah untuk menentukan desa manakah yang menjadi desa siaga. Hasilnya masih diproses secara manual dengan menggunakan perangkat lunak Microsoft Excel yang memiliki banyak 
kelemahan. Penelitian ini akan mengembangkan suatu sistem penunjang keputusan untuk menentukan desa siaga dengan bobot nilai tertinggi di Kecamatan Kalibagor.

Turban (2005) mendefinisikan SPK sebagai sistem informasi berbasis komputer yang adaptif, interaktif, fleksibel, yang secara khusus dikembangkan untuk mendukung solusi dari pemasalahan manajemen yang tidak terstruktur untuk meningkatkan kualitas pengambilan keputusan. Sistem Pendukung Keputusan (Decission Support System) adalah sistem informasi berbasis komputer yang menyediakan dukungan informasi yang interaktif bagi manajer dan praktisi bisnis selama proses pengambilan keputusan. Sistem Pendukung Keputusan menggunakan (1) model analitis, (2) database, (3) penilaian dan pandangan pembuat keputusan dan (4) proses pemodelan berbasis komputer yang interaktif untuk mendukung pembuatan keputusan bisnis yang semi terstruktur (O'Brien, 2005) ${ }^{[6]}$.

Metode AHP ini membantu memecahkan persoalan yang kompleks dengan melakukan struktur terhadap suatu hierarki kriteria, pihak yang berkepentingan, hasil dan dengan menarik berbagai pertimbangan guna mengembangkan bobot atau prioritas. Metode ini juga menggabungkan kekuatan dari perasaan dan logika yang bersangkutan pada berbagai persoalan, lalu mensintesis berbagai pertimbangan yang beragam menjadi hasil yang cocok dengan perkiraan kita secara intuitif sebagaimana yang dipresentasikan pada pertimbangan yang telah dibuat ${ }^{[7]}$.

Logika fuzzy merupakan salah satu komponen pembentuk soft computing. Logika fuzzy pertama kali diperkenalkan oleh Prof. Lotfi A. Zadeh pada tahun 1965. Dasar logika fuzzy adalah teori himpunan fuzzy. Pada teori himpunan fuzzy, peranan derajat keanggotaan sebagai penentu keberadaan elemen dalam suatu himpunan sangatlah penting. Nilai keanggotaan atau derajat keanggotaan atau membership function menjadi ciri utama dari penalaran dengan logika fuzzy tersebut ${ }^{[7]}$.

Implementasi metode AHP untuk pengambilan keputusan telah banyak telah banyak dilakukan, berikut contoh-contoh metpde AHP yang pernah dikembangkan dalam berbagai kasus. Penelitian Rina Fiati, dkk. (2011) membahas tentang 
Pemanfaatan AHP (Analytical Hierarchy Process) sebagai Model Sistem Pendukung Keputusan Penentuan Desa Posdaya, penelitian ini menggunakan kriteria utama dalam menentukan desa mandiri berbasis posdaya dari aspek ekonomi, pendidikan, kesehatan dan lingkungan ${ }^{[3]}$.

Penelitian Jasril, dkk. (2011) tentang Sistem Pendukung Keputusan (SPK) Pemilihan Karyawan Terbaik Menggunakan Metode Fuzzy-AHP (F-AHP). Kriteriakriteria yang digunakan antara lain adalah SOP (Standar Operational Procedure), sikap dan kepribadian, penilaian konsumen, dan penilaian lingkungan kerja atau tim. Metode yang digunakan adalah Fuzzy Analitycal Hierarchy Process dengan pendekatan model Chang $^{[4]}$.

Penelitian Nurrochmah, DPA. dkk (2009) yang membahas tentang Sistem Pendukung Keputusan Perencanaan Strategis Kinerja Instansi Pemerintah Menggunakan Metode AHP (Study Kasus di DEPERINDAG). Bahasa pemrograman yang digunakan adalah Visual Basic dengan database Ms. Access. Kriteria yang digunakan untuk proses perencanaan strategis instansi adalah faktor internal dan eksternal instansi tersebut, kemudian faktor SWOT ${ }^{[5]}$.

Hasil kajian dan riset di atas menunjukkan bahwa metode AHP telah diimplementasikan secara luas, dalam beragam sistem penujang keputusan, dan dapat menjadi solusi untuk integrasi dan interoperabilitas antar sistem informasi yang heterogen.

\section{METODE PENELITIAN}

Penelitian ini dapat digolongkan sebagai penelitian Terapan. Penelitian terapan adalah penelitian yang dikerjakan dengan maksud untuk menerapkan, menguji, dan mengevaluasi kemampuan suatu teori yang diterapakan dalam pemecahan permasalahan praktis.

\section{Alat Penelitian}

Pada penelitian ini menggunakan beberapa perangkat keras. Tabel 1 menjelaskan spesifikasi perangkat keras tersebut. 
Tabel 1. Spesifikasi Perangkat Keras

\begin{tabular}{|l|l|c|}
\hline No & \multicolumn{1}{|c|}{ Spesifikasi } & Jumlah (Unit) \\
\hline 1. & $\begin{array}{l}\text { PC (Personal Computer) : } \\
\text { Processor Core i3 } \\
\text { RAM DDR3 2 GB } \\
\text { Harddisk SATA2 500 GB }\end{array}$ & 1 Unit \\
\hline
\end{tabular}

Perangkat lunak yang digunakan dalam penelitian ini, yaitu sistem operasi Microsoft Windows, ASP.Net mvc4 sebagai bahasa pemrograman yang digunakan untuk membuat sistem informasi pendukung keputusan, SQL Server 2008 sebagai database untuk menampung data yang digunakan, dan Web Matrix sebagai pemrograman web.

2. Tahapan Penelitian

a. Analisis Kebutuhan Fungsional

Pada tahapan ini dilakukan analisis kebutuhan fungsional yang membahas fitur aplikasi yang dibutuhkan oleh user dalam hal ini yaitu Kepala Puskesmas, Camat dan Kepala Dinkes Kabupaten Banyumas untuk berinteraksi dengan komputer. Dokumentasi kebutuhan fungsional menggunakan diagram konteks.

b. Desain Aplikasi

Adapun tahapan proses penelitian dapat dilihat pada diagram alur proses Gambar 1 berikut ini:

\begin{tabular}{|c|c|c|c|}
\hline ANALISIS SISTEM & DESAIN SISTEM & IMPLEMENTASI & PENGUJIAN \\
\hline $\begin{array}{l}\text { 1. Analisis kebutuhan } \\
\text { fungsional }\end{array}$ & $\begin{array}{l}\text { 1. Desain sistem dengan } \\
\text { diagram konteks }\end{array}$ & $\begin{array}{l}\text { Membuat sistem } \\
\text { informasi penunjang }\end{array}$ & $\begin{array}{l}\text { pengujian } \\
\text { fungsional }\end{array}$ \\
\hline $\begin{array}{l}\text { 2. Analisis kebutuhan non } \\
\text { fungsional } \\
\text { 3. Analisis sistem yang } \\
\text { sedang berjalan }\end{array}$ & $\begin{array}{l}\text { 2. Desain } \\
\text { informasi penunjang } \\
\text { keputusan dengan } \\
\text { metode Fuzzy AHP }\end{array}$ & $\begin{array}{l}\text { keputusan dengan } \\
\text { metode Fuzzy AHP }\end{array}$ & sistem \\
\hline & $\begin{array}{l}\text { 3. Desain interface } \\
\text { dengan aplikasi web }\end{array}$ & & \\
\hline
\end{tabular}

Gambar 1. Alur Penelitian 


\section{HASIL DAN PEMBAHASAN}

\section{Analisis Kebutuhan Fungsional}

Kebutuhan fungsional adalah jenis kebutuhan yang berisi proses-proses yang harus

dilakukan oleh sistem. Kebutuhan fungsional dari sistem informasi pendukung keputusan penentuan desa siaga sebagai berikut :

a. Pendataan Desa Siaga

1) User memasukkan data kriteria penentuan desa siaga yaitu keberadaan dan keaktifan forum desa, keberadaan kader pemberdayaan masyarakat, kemudahan akses masyarakat terhadap pelayanan kesehatan, keberadaan UKBM, tercakupnya pendanaan untuk pengembangan desa, peran serta aktif masyarakat dan organisasi kemasyarakatan, peraturan ditingkat desa yang melandasi dan mengatur tentang pengembangan desa, pembinaan Perilaku Hidup Bersih dan Sehat (PHBS) di desa.

2) User dapat memasukkan data untuk kriteria baru apabila diperlukan kriteria baru.

3) Kepala Puskesmas dapat memasukkan data untuk kriteria baru apabila diperlukan kriteria baru.

\section{b. Perhitungan Fuzzy AHP}

1) Kepala Puskesmas dapat memasukkan nilai bobot untuk penentuan desa siaga, yaitu ditentukan oleh keberadaan dan keaktifan forum desa, keberadaan kader pemberdayaan masyarakat, kemudahan akses masyarakat terhadap pelayanan kesehatan, keberadaan UKBM, tercakupnya pendanaan untuk pengembangan desa, peran serta aktif masyarakat dan organisasi kemasyarakatan, peraturan ditingkat desa yang melandasi dan mengatur tentang pengembangan desa, pembinaan Perilaku Hidup Bersih dan Sehat (PHBS) di desa.

2) Camat dapat memasukkan nilai bobot untuk penentuan desa siaga, yaitu ditentukan oleh keberadaan dan keaktifan forum desa, keberadaan kader pemberdayaan masyarakat, kemudahan akses masyarakat terhadap 
pelayanan kesehatan, keberadaan UKBM, tercakupnya pendanaan untuk pengembangan desa, peran serta aktif masyarakat dan organisasi kemasyarakatan, peraturan ditingkat desa yang melandasi dan mengatur tentang pengembangan desa, pembinaan Perilaku Hidup Bersih dan Sehat (PHBS) di desa.

3) Kepala Dinas Kesehatan dapat memasukkan nilai bobot untuk penentuan desa siaga, yaitu ditentukan oleh keberadaan dan keaktifan forum desa, keberadaan kader pemberdayaan masyarakat, kemudahan akses masyarakat terhadap pelayanan kesehatan, keberadaan UKBM, tercakupnya pendanaan untuk pengembangan desa, peran serta aktif masyarakat dan organisasi kemasyarakatan, peraturan ditingkat desa yang melandasi dan mengatur tentang pengembangan desa, pembinaan Perilaku Hidup Bersih dan Sehat (PHBS) di desa.

c. Output dari sistem informasi pendukung keputusan penentuan desa siaga di Puskesmas Kalibagor berupa data perangkingan desa siaga selama periode satu bulan. Output tersebut dalam bentuk tabel yang memperlihatkan nilai bobot masing-masing kriteria yaitu ada sembilan kriteria penentuan desa siaga untuk dua belas alternatif yaitu 12 desa di Kecamatan Kalibagor yang telah diproses dengan metode Fuzzy AHP.

\section{Analisis Kebutuhan Non-Fungsional}

Analisis kebutuhan non fungsional dilakukan untuk mengetahui spesifikasi kebutuhan untuk sistem. Spesifikasi kebutuhan melibatkan analisis perangkat keras/hardware, analisis perangkat lunak/software, analisis pengguna/user.

\section{a. Hardware}

Komputer dengan spesifikasi sesuai untuk menjalankan software dalam penelitian dengan spesifikasi: PC (Personal Computer) : processor Core i3, RAM DDR3 2 GB dan harddisk SATA2 500 GB 
b. Software

1) Digunakan pada sistem operasi Microsoft Windows.

2) ASP.Net mvc4 sebagai bahasa pemrograman.

3) SQL Server 2008 sebagai database.

4) Web Matrix sebagai pemrograman web.

\section{c. Brainware}

Perangkat manusia memegang peranan penting dalam pengembangan suatu sistem, perangkat inilah yang nantinya akan mengoperasikan teknologi tersebut. Oleh karena itu perlu dilakukan pelatihan terhadap perangkat manusia yang akan menggunakan sistem baru tersebut nantinya. Adapun kebutuhan perangkat manusia yang dibutuhkan adalah admin/user. User ini memiliki hak penuh untuk melakukan pengaturan sistem dan tidak semua orang memiliki hak yang sama. Hal tersebut demi keamanan sistem yang ada.

\section{Operasional}

Terkoneksi internet baik pihak Puskesmas Kalibagor maupun Dinas Kesehatan Kabupaten Banyumas.

\section{Security}

Puskesmas Kalibagor mempunyai hak akses terhadap sistem informasi pendukung keputusan penentuan desa siaga yang ada di Dinas Kesehatan Kabupaten Banyumas.

\section{Informasi}

Digunakan untuk menampilkan sistem informasi pendukung keputusan penentuan desa siaga pada website Dinas Kesehatan Kabupaten Banyumas.

\section{Performance}

Bidan desa yang ada di Puskesmas Kalibagor mampu menampilkan data desa dengan pencapaian target KIA tertinggi dalam setiap bulannya. 
7. Analisis Manajemen Data

Berikut adalah data-data yang dibutuhkan dalam membentuk sebuah komponen manajemen database, dalam rangka membangun sistem informasi pendukung keputusan guna membantu proses penentuan desa siaga yang tepat terdiri dari:

a. Data Internal

Berupa data 9 (sembilan) kriteria/indikator penentuan desa siaga yaitu antara lain keberadaan dan keaktifan forum desa, keberadaan kader pemberdayaan masyarakat, kemudahan akses masyarakat terhadap pelayanan kesehatan, keberadaan UKBM, tercakupnya pendanaan untuk pengembangan desa, peran serta aktif masyarakat dan organisasi kemasyarakatan, peraturan ditingkat desa yang melandasi dan mengatur tentang pengembangan desa, pembinaan Perilaku Hidup Bersih dan Sehat (PHBS) di desa, data desa, serta data lain yang mendukung dalam menentukan proses penentuan desa siaga.

b. Data Privat

Penentuan item-item dari aspek-aspek yang telah ditentukan sebelumnya (data bidan desa).

8. Analisis Manajemen Model

a. Rancangan Sistem

\section{1) Context Diagram}

Dengan pembuatan suatu diagram konteks dari sistem, pendekatan struktur ini mengambarkan sistem secara garis besar yang kemudian akan dipecah menjadi bagian-bagian lebih rinci. Gambar berikut ini adalah context diagram dari Sistem Informasi Pendukung Keputusan Penentuan Desa Siaga di Puskesmas Kalibagor Kabupaten Banyumas: 


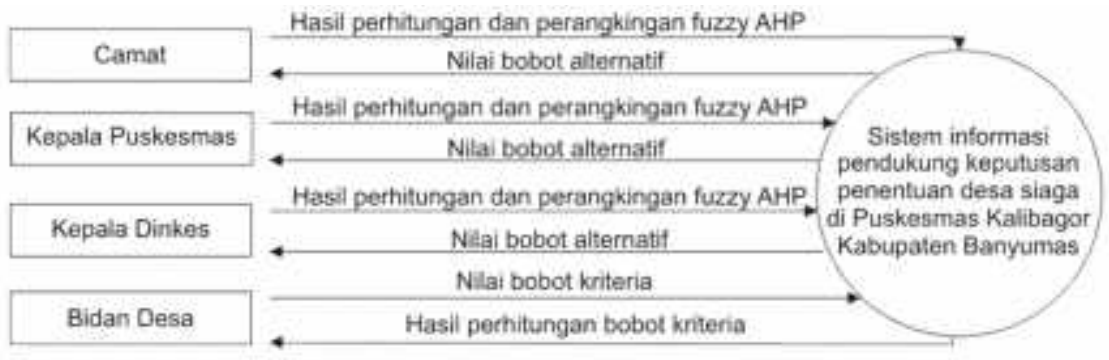

Gambar 2. Context Diagram Sistem Pendukung Keputusan Penentuan Desa

Siaga

Pada gambar diagram konteks dijelaskan bahwa yang menggunakan sistem informasi pendukung keputusan penentuan desa siaga menggunakan Fuzzy AHP adalah user (pengguna), pengguna adalah orang yang memberikan bobot penilaian kepada desa siaga di Kecamatan Kalibagor. Pengguna dapat berinteraksi langsung dengan sistem dengan memberikan masukan berupa data kriteria dan bobot kriteria, kemudian sistem memberikan umpan balik berupa hasil perhitungan dan hasil perangkingan menggunakan Fuzzy AHP.

2) Struktur Hierarki Sistem Informasi Penunjang Keputusan

Penilaian alternatif pada sistem informasi pendukung keputusan penentuan desa siaga di Pusksmas Kalibagor Kabupaten Banyumas ini dilakukan dengan metode langsung (direct), yaitu metode yang digunakan untuk memasukkan data kuantitatif. Biasanya nilai-nilai ini berasal dari sebuah analisis sebelumnya atau dari pengalaman dan pengertian yang detail dari masalah keputusan tersebut. Jika pengambil keputusan memiliki pengalaman atau pemahaman yang baik mengenai masalah yang dihadapi, maka pengambil keputusan dapat langsung memasukkan pembobotan dari setiap alternatif. 


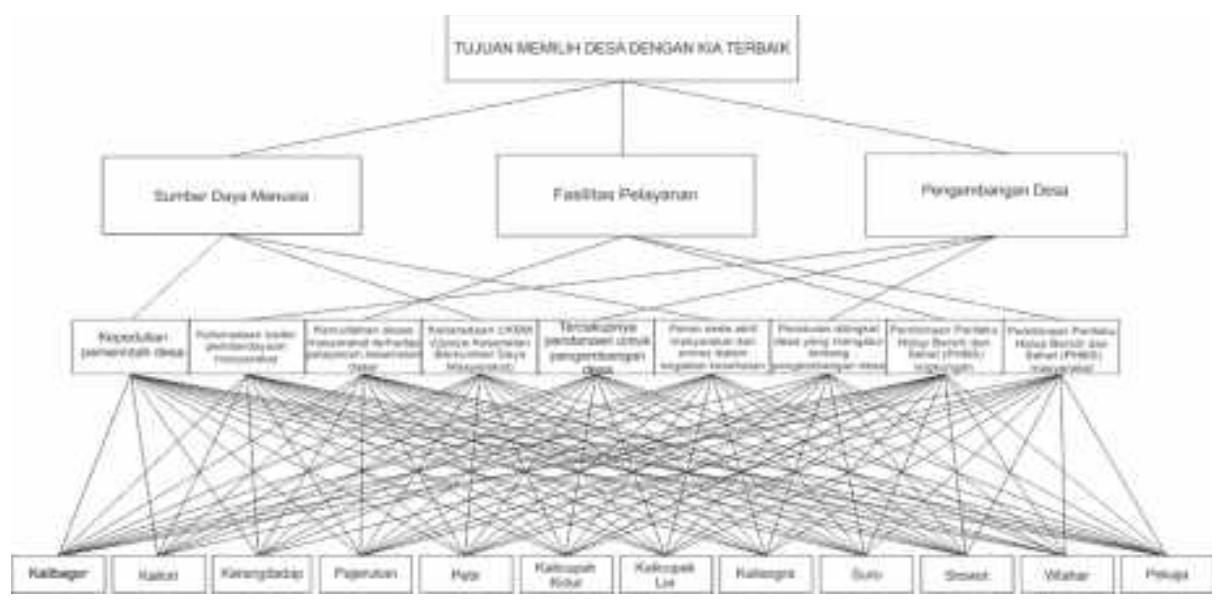

Gambar 3. Struktur Hierarki Sistem Informasi Penunjang Keputusan

Keterangan Gambar 4:

a) Hierarki terbawah adalah nama-nama desa di Kecamatan Kalibagor Kabupaten Banyumas.

b) Hierarki kedua adalah kriteria-kriteria yang dipakai untuk menganalisis penentuan desa siaga dengan pencapaian target tertinggi yaitu 11 indikator dasar pelayanan KIA yg dikelompokkan menjadi tiga kelompok.

c) Hierarki ketiga adalah hierarki yang berisi nama desa dengan pencapaian target KIA tertinggi. Desa inilah yang menjadi desa percontohan di Kecamatan Kalibagor Kabupaten Banyumas.

9. Implementasi

a. Tampilan User Interface

Tampilan halaman utama dari website sistem informasi penunjang keputusan penentuan desa siaga di Puskesmas kalibagor Kabupaten Banyumas. 


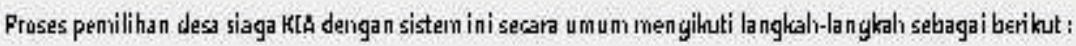

2 Menyigplian Dita

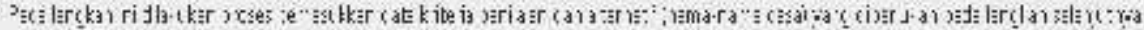

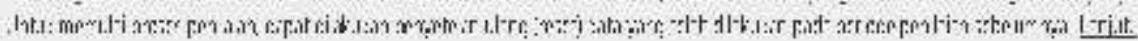

2 Molokukar Penllsan

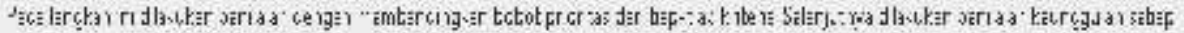

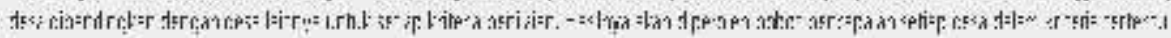
Lillen

3 Menpambil Kepubsean

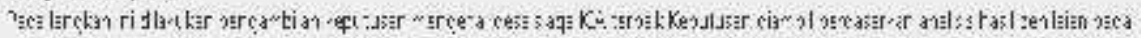

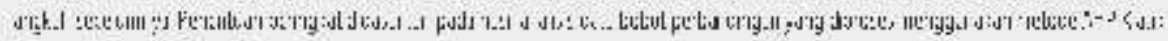

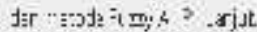

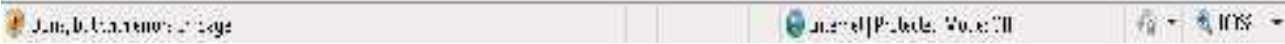

\section{Gambar 4: Tampilan Halaman Utama Website Sistem Informasi Penunjang}

\section{Keputusan}

\section{b. Tampilan Halaman Analisis}

Tampilan halaman analisis untuk menganalisis tiap-tiap kriteria yang dibagi menjadi 3 yaitu pelayanan ibu hamil, pelayanan bayi dan pelayanan balita.

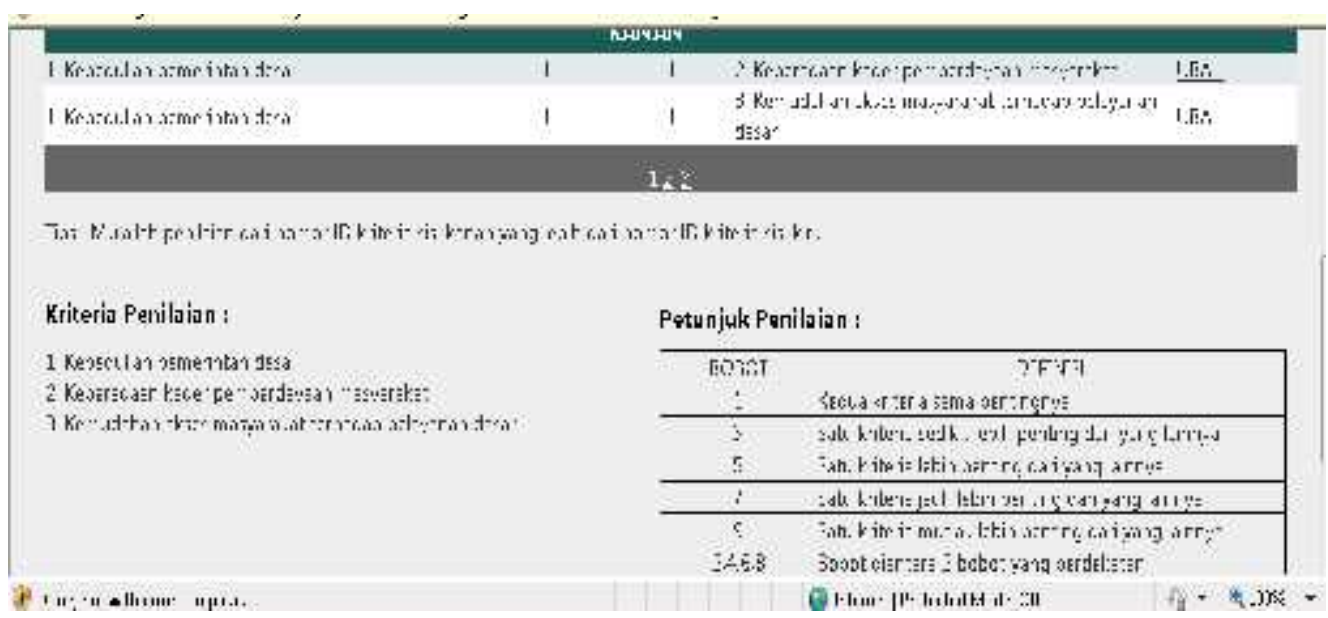

Gambar 5: Tampilan Halaman Analisis Sistem Informasi Penunjang

Keputusan 
c. Tampilan Halaman Hasil

Berikut tampilan halaman hasil penilaian bobot kriteria dan bobot alternatif penilaian desa siaga di Kecamatan Kalibagor:

\begin{tabular}{|c|c|c|c|c|c|c|c|c|c|c|c|}
\hline \multicolumn{12}{|c|}{ 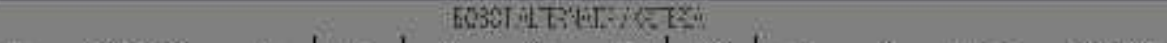 } \\
\hline \multirow[t]{2}{*}{ If: } & \multirow[t]{2}{*}{ NoLAROSE } & K & $k$ & 0 & 经 & K & K. & हर & $\mathrm{Ki}$ & \multirow[t]{2}{*}{$d V=$} & \multirow[t]{2}{*}{ Frolse] } \\
\hline & & 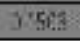 & $6 \cos ^{2}$ & c.1\%1! & $9+365$ & 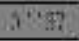 & 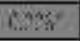 & 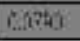 & $\sin 2$ & & \\
\hline$\therefore 1$ & Sallidig & iH... & intis & Dinlil & $\sin x$ & i1) & Fills & Wos & itited & iH:- & : \\
\hline$\therefore$ & Saler & $\mathrm{Jc}: 4$ & $(0) 03$ & (.). 1131 & JC:.E & Jecese & (.J13) & c.055s' & Jecet & $j[74:$ & $\because$ \\
\hline & 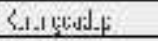 & 3054 & inis? & D.101 & II:. & $\operatorname{inces}$ & i. 1134 & nirss & $\min$ & 3172 & $i$ \\
\hline$\ddot{H}$ & Jajerdat & $30 \%:$ & tojog & WIjI & 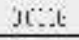 & jto & inly & Cos's & Jitk4 & $\pi i t$ & $\because$. \\
\hline & $e^{2}-1$ & mot & A. ins & i.111 & $3 t^{\prime \prime}$ & $\sin$ & i..it3: & H.jus & mirt & $\sin$ & $?$ \\
\hline & Salupisitisit & Wit: & Diws & binil & 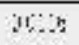 & and & bills & abs & ibted & i4:\% & s \\
\hline 87 & $\langle a| a . F s \cdot b$ & $x:: x^{4}$ & $(0)=3$ & (.). 1131 & JC:.E & uecer: & (.).133 & $() 5 y=$. & $\mathrm{xeces}$ & $J 6 G_{4}$ & 5 \\
\hline & K-1ocer & 10,1 & 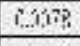 & $8.11 \%$ & an' & $\operatorname{sines}$ & 8...1124 & ion & 310.1 & ins'i & $?$ \\
\hline & 250 & 11."." & nowit & WIII & ai:... & $\operatorname{now}$ & biltet & Dots & wh:4 & sube? & 4 \\
\hline & irrost & $\sin 9 ?$ & follis & colyi & $\mathrm{MF}_{\mathrm{F}}$ & mroc & 6...19. & comśs & Ifreft & 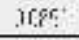 & $?$ \\
\hline & 781.1s & Min? & $i \ldots 9 ?$ & Einlí1 & 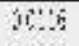 & $\operatorname{sins}$ & ini134 & D.,015s & sions & 3655 & 2 \\
\hline & Pakzj: & 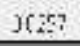 & $(0)=9$ & (.J1)1 & $\mathrm{x}: \mathrm{E}$ & Jecer & (.).133 & $(.3955$ & Jeces & jesce & $\therefore$ \\
\hline & & & & TOTHL & & & & & & & 93 \\
\hline
\end{tabular}

Gambar 6. Tampilan Halaman Hasil Sistem Informasi Penunjang Keputusan

\section{KESIMPULAN DAN SARAN}

1. Kesimpulan

Dari hasil penelitian yang dilakukan dari tahap awal sampai dengan proses pengujian, dapat disimpulkan bahwa dengan diimplementasikannya Sistem Informasi Penunjang Keputusan Penentuan Desa Siaga di Puskesmas Kalibagor Kabupaten Banyumas disimpulkan sebagai berikut :

a. Sistem dapat menerapkan metode F-AHP dalam menentukan desa siaga dengan cara bidan desa memberikan bobot nilai terhadap setiap kriteria yang dibandingkan dan tim penilai yaitu Camat, Kepala Puskesmas Kalibagor, Kepala Dinas Kesehatan Kabupaten Banyumas memberikan bobot nilai terhadap setiap alternatif/desa di Kecamatan Kalibagor maka diperoleh hasil yaitu desa siaga di Kecamatan Kalibagor dengan bobot nilai tertinggi

b. Sistem dapat membantu mencari dan menentukan desa siaga di Puskesmas Kalibagor dengan memberikan bobot nilai kepada kriteria desa siaga yaitu 9 (sembilan) indikator/kriteria desa siaga yang telah ditentukan oleh Keputusan 
Menteri Kesehatan Republik Indonesia Nomor 564/MENKES/SK/VI II/2006, tentang Pedoman Pelaksanaan Pengembangan Desa Siaga, antara lain keberadaan dan keaktifan forum desa, keberadaan kader pemberdayaan masyarakat, kemudahan akses masyarakat terhadap pelayanan kesehatan, keberadaan UKBM, tercakupnya pendanaan untuk pengembangan desa, peran aktif masyarakat dan organisasi kemasyarakatan, peraturan ditingkat desa yang melandasi dan mengatur tentang pengembangan desa, pembinaan Perilaku Hidup Bersih dan Sehat (PHBS) di desa.

c. Perancangan dan implementasi untuk membuat sistem informasi pendukung keputusan yang diterapkan dalam bidang kesehatan khususnya penentuan desa siaga di Puskesmas Kalibagor yaitu dengan menggunakan metode F-AHP yang membandingkan bobot nilai setiap kriteria desa siaga untuk setiap alternatif/desa di Kecamatan Kalibagor dan membandingkan bobot nilai setiap alternatif, sehingga diperoleh sebuah keputusan yaitu desa dengan bobot nilai tertinggi. Implementasinya berupa sistem informasi pendukung keputusan menggunakan metode F-AHP untuk menentukan desa siaga yang diterapkan di Puskesmas Kalibagor.

d. Manfaat yang diperoleh dengan menerapkan metode Fuzzy AHP dalam penentuan desa siaga ini yaitu dapat mengembangkan sebuah aplikasi pendukung keputusan yang dapat memberikan rekomendasi alternatif untuk pengambil keputusan, sehingga proses penentuan desa siaga dapat berlangsung secara efektif dan efisien serta menghasilkan keputusan yang objektif.

e. Manfaat yang diperoleh yaitu sebagai suatu usaha untuk mendapatkan solusi terbaik atas permasalahan multiple criteria decision making dapat digunakan Fuzzy Analitical Hierarky Process (F-AHP), yang dalam implementasinya akan memunculkan beberapa alternatif solusi berdasarkan hasil ranking kumulatif, yang kemudian dapat dipilih satu solusi tertentu, berdasarkan kriteria tambahan dari pemegang kebijakan (pimpinan). Kemudian, beberapa 
alternatif solusi tersebut dapat dijadikan referensi tim pengambil keputusan untuk diajukan kepada pimpinan mereka, sehingga pimpinan mereka dapat memilih satu solusi dari beberapa alternatif solusi yang ada, dan diharapkan dapat diambil keputusan terbaik yang menguntungkan.

2. Saran

Berdasarkan hasil yang ditemukan dan dicapai pada penelitian ini, maka terdapat beberapa saran yang dapat diberikan, antara lain:

a. Melakukan pengujian dengan metode yang berbeda.

b. Melakukan pengujian berdasarkan pengaruh jarak kelahiran pada sebuah keluarga .

\section{DAFTAR PUSTAKA}

[1] Depkes RI. Modul Surveilans KIA : Peningkatan Kapasitas Agen Perubahan dan Pelaksanaan Program Kesehatan Ibu dan Anak. Dirjen Bina Kesehatan Masyarakat, Jakarta, 2007.

[2] Peraturan Menteri Kesehatan Republik Indonesia Nomor 564/Menkes/PER/VII/2008 tentang Pedoman Pelaksanaan Pengembangan Desa Siaga

[3] Fiati, Rina, dkk. (2011) Pemanfaatan AHP (Analytical Hierarchy Process) sebagai Model Sistem Pendukung Keputusan Penentuan Desa Posdaya

[4] Jasril, dkk. (2011) Sistem Pendukung Keputusan (SPK) Pemilihan Karyawan Terbaik Menggunakan Metode Fuzzy-AHP (F-AHP)

[5] Nurrochmah, DPA. dkk (2009) Sistem Pendukung Keputusan Perencanaan Strategis Kinerja Instansi Pemerintah Menggunakan Metode AHP

[6] Turban Efraim, Aronson Jay E, 2005," Decision Support System and Intelegent System. $" 5{ }^{\text {th }}$ Edition, Prentice-hall International, Inc.

[7] Kabir dan Ahsan, (2011), Comparative Analysis of AHP and Fuzzy AHP Models for MulticriteriaInventory Classification, International Journal of Fuzzy Logic Sistems (IJFLS).

[8] Pressman, Roger, S., "Software Engineering: A Practitioner's Approach fifth edition”, Mc Graw Hill, New York, 2001. 